\title{
Lokalne innowacje społeczne wspierające rozwój i funkcjonowanie przedsiębiorczości
}

\author{
Anna Michna*, Anna Męczyńska** \\ Streszczenie: Na stan lokalnej przedsiębiorczości duży wpływ mają działania podejmowane przez jednostki \\ samorządu terytorialnego. Badania pokazują, że najczęściej wspieranie przedsiębiorczości ogra- \\ nicza się do stosowania w różnym zakresie instrumentów finansowych i działań promocyjnych. \\ Celem artykułu jest przedstawienie nowatorskich, usystematyzowanych, realizowanych lokalnie \\ przez UM w Zabrzu innowacji społecznych - nowych rozwiązań, które mają wspierać rozwój \\ i funkcjonowanie przedsiębiorczości. Zastosowanie tych innowacyjnych rozwiązań powinno przy- \\ nosić społeczeństwu określone utylitarne i mierzalne korzyści. Działania te ujęte są w „Lokalnym \\ programie przedsiębiorczości na lata 2016-2020".
}

Słowa kluczowe: zarządzanie publiczne, innowacje społeczne, wspieranie przedsiębiorczości.

\section{Wprowadzenie}

Działania podejmowane przez jednostki samorządu terytorialnego wpływają istotnie na stan regionu poprzez kształtowanie warunków społeczno-ekonomicznych. Stąd pożądane są takie działania, które prowadzą do ciągłej poprawy sytuacji ekonomicznej oraz jakości dóbr i usług dostarczanych lokalnej społeczności, czyli rozwoju lokalnego. Rozwój lokalny jest procesem, rozumianym jako ustawiczne „prowadzenie działań na rzecz rozwoju społeczno-gospodarczego danej jednostki terytorialnej, z wykorzystaniem jej zasobów oraz uwzględnieniem potrzeb mieszkańców i równocześnie przy ich udziale" [Kożuch, 2011]. Zatem tematyka ta usytuowana jest w subdyscyplinie Zarzqdzanie publiczne i NGO [Cyfert i inni, 2014].

Ponieważ działania podejmowane przez jednostki samorządu terytorialnego wpływają (pozytywnie lub negatywnie) na stan lokalnej przedsiębiorczości [Matejun, 2012], natomiast poziom przedsiębiorczości rzu- tuje na sposób funkcjonowania społeczności lokalnej i wpływa na określenie jej potrzeb, a warunki, w których funkcjonuje ta społeczność szybko się zmieniają, więc w niniejszym artykule skoncentrowano się na lokalnych sposobach wzmacniania przedsiębiorczości. Typowe instrumenty finansowe wykorzystywane przez jednostki samorządu terytorialnego do wspierania przedsiębiorczości na ogół nie są wystarczające, więc jednostki te próbują wprowadzać innowacje społeczne. W pracy przedstawiono przykład innowacji

\footnotetext{
* Anna Michna

Instytut Ekonomii i Informatyki

Wydział Organizacji i Zarządzania

Politechnika Śląska

ul. Roosevelta 26, 41-800 Zabrze

e-mail:anna.michna@polsl.pl

** Anna Męczyńska Instytut Ekonomii i Informatyki Wydział Organizacji i Zarządzania Politechnika Śląska ul. Roosevelta 26, 41-800 Zabrze e-mail: annameczynska@polsı.pl
} 
społecznej w tym zakresie realizowanej na terenie jednego z miast aglomeracji górnośląskiej - Zabrza.

\section{Instrumenty wspierania przedsiębiorczości}

Definicje osoby przedsiębiorczej, działań przedsiębiorczych oraz przedsiębiorczości zostały wypracowane w ramach Programu Wskaźników Przedsiębiorczości przez OECD we współpracy z Eurostatem [GUS, 2016]. Przyjęto, że:

- osoby przedsiębiorcze to osoby, które próbują generować wartość poprzez kreację lub rozwój działalności gospodarczej, dzięki rozpoznawaniu i wykorzystywaniu szans związanych z nowymi produktami, procesami lub rynkami;

- działania przedsiębiorcze to działania osób przedsiębiorczych w dążeniu do generowania wartości przez kreację lub rozwój działalności, dzięki rozpoznawaniu i wykorzystywaniu szans związanych z nowymi produktami, procesami lub rynkami;

- przedsiębiorczość to zjawisko łączące się z działaniami przedsiębiorczymi ludzi przedsiębiorczych.

Z punktu widzenia lokalnego rozwoju istotne jest wsparcie przedsiębiorczości przez lokalne jednostki samorządu terytorialnego - gminy. Gminy mają wiele instrumentów wsparcia [Skica, Bem, 2014; Dziemianowicz i inni, 2000]. Instrumenty te można podzielić na:

1. Instrumenty dochodowe

- ulgi podatkowe,

- zwolnienia podatkowe,

- obniżenie maksymalnych stawek opłat i podatków lokalnych,

- odraczanie, umarzanie, rozłożenie na raty zobowiązań podatkowych,

- zaniechanie poboru podatków,

- polityka czynszowa gminy,

- polityka cen za usługi komunalne,

- polityka prywatyzacyjna;
2. Instrumenty wydatkowe

- inwestycje w infrastrukturę techniczną (sieć transportowa, zaopatrzenie w media, przygotowanie terenów pod inwestycje),

- inwestycje w infrastrukturę społeczną i rozwój rynku pracy,

- instytucje wsparcia biznesu (fundusze pożyczkowe, fundusze poręczeń, pomoc techniczna, agencje rozwoju, inkubatory przedsiębiorczości, centra i parki technologiczne, centra wspierania biznesu itp.),

- promocja gminy, promocja lokalnych produktów i współpracy lokalnych przedsiębiorców.

Inny podział to:

1. Instrumenty finansowe

- budżet gminy,

- ulgi, zwolnienia podatkowe, stawki podatków i opłat lokalnych,

- polityka cen za usługi komunalne,

- wydatki inwestycyjne,

- fundusze pożyczkowe oraz fundusze poręczeń;

2. Instrumenty pozafinansowe

- instytucje wsparcia biznesu (pomoc techniczna, agencje rozwoju, inkubatory przedsiębiorczości, parki technologiczne itp.),

- rozwój rynku pracy,

- promocja gminy, promocja lokalnych produktów i współpracy lokalnych przedsiębiorców,

- stabilna polityka podatkowa, czynszowa i prywatyzacyjna gminy,

- strategia rozwoju gminy,

- „przyjazny klimat” dla inwestorów, pozytywne nastawienie lokalnych społeczności.

Można wyróżnić też:

1. Instrumenty wywierajace wpływ na podmioty gospodarcze (ulgi podatkowe, nakazy administracyjne itp.),

2. Instrumenty wywierajace wpływ na otoczenie podmiotów gospodarczych (np. infrastruktura techniczna, stan środowiska naturalnego). 
Inna klasyfikacja obejmuje:

1. Instrumenty obligatoryjne (w świetle prawa),

2. Instrumenty fakultatywne (z inicjatywy samej jednostki samorządowej).

Jednostki terytorialne $w$ różnym stopniu wykorzystują instrumenty wspierające przedsiębiorczość. Wynika to głównie ze zróżnicowania regionów pod względem rozwoju, zasobności, dostępności różnych zasobów (materialnych i niematerialnych), możliwości finansowych. Należy zauważyć, że niektóre instrumenty wspierające powinny być stosowane ze szczególną ostrożnością i poprzedzone rzetelną analizą pod kątem ich opłacalności dla budżetu. Przykładowo, w przypadku dużych inwestorów zagranicznych ulga podatkowa poniżej jednego promila obrotów inwestora może znacznie uszczuplić budżet gminy. Ponadto trzeba pamiętać, że dla przedsiębiorców szczególnie istotna jest przejrzystość i stabilność stosowanych rozwiązań.

\section{Przedsiębiorczość i jej wspieranie przez jednostki terytorialne}

W lipcu 2012 r. Biuro Analiz Sejmowych wysłało ankietę do 2.793 jednostek samorządu terytorialnego (JST) - gmin, powiatów i miast na prawach powiatu, dotyczącą wspierania rozwoju przedsiębiorczości przez te jednostki; zwrócono 1.436 (51,4\%) ankiet [Ciura i inni, 2013]. Miasta na prawach powiatu reprezentowało 3,9\% (56) respondentów, powiaty - 10,2\% (146), gminy miejskie - 10,7\% (154), gminy wiejskie - 52,4\% (752) i gminy miejsko-wiejskie - 22,8\% (327). Zwrot ankiet w poszczególnych kategoriach JST był następujący: miasta na prawach powiatu $-86,2 \%$, powiaty - 46,5\%, gminy miejskie - 63,9\%, gminy wiejskie - $47,9 \%$ i gminy miejsko-wiejskie $-54,3 \%$.

Prawie 96\% respondentów stwierdziło, że stosowało stawki podatku od nieruchomości niższe niż maksymalne, przy czym częściej po ten instrument sięgały gminy wiejskie $(96,1 \%)$ i miejsko-wiejskie (97,9\%), aniżeli gminy miejskie $(93,5 \%)$ i miasta na prawach powiatu (89,3\%). W 2012 r. maksymalna ustawowa roczna stawka podatku wynosiła: 21,94 zł/ $\mathrm{m}^{2}$ dla budynków i 0,84zł/m² dla gruntów, natomiast obniżone stawki podatku wskazane przez respondentów wahały się: dla budynków od $0,02 \mathrm{z} t / \mathrm{m}^{2}$ do $21,93 \mathrm{z} t / \mathrm{m}^{2}$, a dla gruntów od $0,30 \mathrm{z} ł / \mathrm{m}^{2}$ do $0,83 \mathrm{zł} / \mathrm{m}^{2}$; mediany wynosiły odpowiednio $18,50 \mathrm{z} ł / \mathrm{m}^{2} \mathrm{i} 0,74 \mathrm{z} \mathrm{z} / \mathrm{m}^{2}$.

$99,6 \%$ jednostek biorących udział w badaniu wypowiedziało się $w$ sprawie udzielania ulg, umorzeń i zwolnień w podatku od nieruchomości podmiotom prowadzącym działalność gospodarczą. 83\% respondentów stwierdziło, że stosuje ten instrument wspierania przedsiębiorczości, przy czym prawie co czwarta gmina wiejska nie korzysta z tego instrumentu, natomiast w pozostałych kategoriach JST ponad 92\% sięga po ten instrument finansowy. Ubytek dochodów z tytułu udzielanych ulg, umorzeń i zwolnień w podatku od nieruchomości w 2011 r. wyniósł łącznie 265.275.792 zł, a w poszczególnych JST wahał się od 22 zł do 10.470 .605 zł; mediana wynosiła 24.103 zł.

Jednostki samorządu terytorialnego prowadzą różne inwestycje. Na ten temat wypowiedziało się 89,7\% biorących udział w badaniu. Prawie we wszystkich kategoriach JST (z wyjątkiem gmin wiejskich) najczęściej wskazywano inwestycje w infrastrukturę komunikacyjną (76,6\% ogółu respondentów), natomiast gminy wiejskie najczęściej inwestowały w infrastrukturę komunalną. W infrastrukturę komunalną inwestowało $63,6 \%$ ogółu respondentów. Wyraźnie rzadziej JST inwestowały w infrastrukturę sportu, rekreacji turystyki i kultury (21\% ogółu respondentów) oraz w infrastrukturę społeczną (12,8\% ogółu respondentów).

Prawie $2 / 3$ respondentów $(65,4 \%)$ stwierdziło, że nie udzielało poręczeń i gwarancji. Najczęściej poręczeń udzielały miasta na prawach powiatu (aż 71,4\% spośród badanych 
JST tej kategorii), najrzadziej z tego instrumentu korzystały gminy wiejskie (22,4\%).

Większość badanych JST (78,2\%) nie powoływała instytucji otoczenia biznesu, wspierających przedsiębiorczość. Najbardziej w takie działania angażowały się miasta na prawach powiatu (aż 94,6\% JST tej kategorii), natomiast najmniejsze zaangażowanie w tym zakresie wykazały gminy wiejskie (tylko 9,0\% JST tej kategorii).

99,2\% ankietowanych udzieliło odpowiedzi na pytanie: „Czy jednostka w okresie 20072012 analizowała stan przedsiębiorczości na swoim terenie?". W przypadku pozytywnej odpowiedzi należało wskazać trzy główne bariery rozwoju przedsiębiorczości. Okazało się, że aż 76,9\% respondentów odpowiedziało negatywnie. Częstość negatywnych odpowiedzi w poszczególnych kategoriach JST była następująca: gminy wiejskie - 85,7\%, miasta na prawach powiatu - 76,8\%, gminy miejsko-wiejskie - 74,7\%, powiaty - 69,4\%, gminy miejskie - 65,4\%. Jako główne bariery respondenci wskazali: związane ze stanem infrastruktury $(26,6 \%)$, ekonomiczne $(17,1 \%)$, finansowe (10,3\%), społeczne (9,5\%), prawno-administracyjne $(9,2 \%)$.

Prawie wszystkie JST (95,6\% ogółu badanych) prowadziły działalność promocyjną. Wśród podmiotów, które nie prowadzą takiej działalności (4,2\% ogółu badanych) przeważają gminy wiejskie $(81,7 \%)$ i miejsko-wiejskie (15\%). Wśród celów strategicznych promocji $71 \%$ badanych uwzględniło cele gospodarcze, takie jak: przyciąganie nowych inwestorów (56,8\%), pobudzanie przedsiębiorczości mieszkańców (46,5\%), rozwój przedsiębiorczości (41\%), przyciąganie inwestorów z innowacyjnych branż (17,3\%).

Jedynie $28 \%$ ogółu badanych zadeklarowało przeprowadzanie szerokich konsultacji ze środowiskiem przedsiębiorców w sprawach związanych z polityką gospodarczą. Takie konsultacje przeprowadziło $83,9 \%$ badanych miast na prawach powiatu, $44,9 \%$ badanych gmin miejskich, $41,6 \%$ badanych powia- tów, 33,9\% badanych gmin miejsko-wiejskich oraz $15,2 \%$ badanych gmin wiejskich. W 27,3\% badanych JST funkcjonuje "rozwiązanie organizacyjne umożliwiające regularną współpracę z lokalnymi przedsiębiorcami", przy czym funkcjonowanie takiego rozwiązania deklarowało $83,9 \%$ badanych miast na prawach powiatu, 46,9\% gmin miejskich, 38,9\% powiatów, 31,8\% gmin miejsko-wiejskich oraz 14,9\% badanych gmin wiejskich; najczęściej były to spotkania konsultacyjno-dyskusyjne z samorządami gospodarczymi lub ze stowarzyszeniami przedsiębiorców.

Zaledwie $8,9 \%$ badanych JST prowadzi badania opinii przedsiębiorców. Na stosowanie tego instrumentu wskazało 53,6\% badanych miast na prawach powiatu, 20,8\% gmin miejskich, 11,6\% powiatów, 9,2\% gmin miejsko-wiejskich i 2,5\% badanych gmin wiejskich.

Tylko 42 JST (2,9\% ogółu badanych) przyjęło lokalny program rozwoju przedsiębiorczości; w tym: 10 miast na prawach powiatu (17,9\% respondentów z tej kategorii JST), 8 powiatów (5,5\%), 13 gmin miejsko-wiejskich (4,0\%), 6 gmin miejskich (3,9\%), 5 gmin wiejskich $(0,7 \%)$.

$\mathrm{Na}$ podstawie przedstawionych wyników badań można stwierdzić, że stosunkowo powszechne, niejako „standardowe”, jest stosowanie instrumentów finansowych (obniżonych stawek podatkowych i udzielanie ulg, umorzeń i zwolnień od podatku), inwestowanie (głównie w infrastrukturę komunikacyjną i komunalną) oraz prowadzenie działalności promocyjnej. Wśród działań, które są stosunkowo rzadko podejmowane, a które mogą istotnie wpłynąć na podniesienie lokalnej przedsiębiorczości są: analiza stanu przedsiębiorczości na danym terenie, szerokie konsultacje i stała współpraca z lokalnymi przedsiębiorcami, a w konsekwencji systemowe podejście do problemu wspierania lokalnej przedsiębiorczości i np. opracowanie i wdrożenie lokalnego programu rozwoju przedsiębiorczości. Należy zauważyć, że wśród tych 
nielicznych ponadstandardowych działań przodują miasta na prawach powiatu, gminy miejskie i powiaty.

\section{Lokalny plan rozwoju przedsiębiorczości w Zabrzu}

Władze Zabrza uznały, że dotychczasowe wsparcie dla przedsiębiorczości jest niewystarczające i postanowiono opracować kompleksowy „Lokalny plan rozwoju przedsiębiorczości dla miasta Zabrze na lata 2016$2020^{\prime 1}$, który obecnie jest wdrażany. Opracowanie planu poprzedzone było badaniami ankietowymi przeprowadzonymi wśród zabrzańskich przedsiębiorców, które dotyczyły klimatu przedsiębiorczości i warunków prowadzenia działalności gospodarczej. Władze miasta chciały poznać oczekiwania i preferencje przedsiębiorców, informacje te miały być podstawą stworzenia dogodniejszych warunków prowadzenia działalności gospodarczej.

W badaniu wzięło udział 375 przedstawicieli firm, z czego 73,6\% było właścicielami lub współwłaścicielami, zatem najlepiej znali klimat dla przedsiębiorczości w Zabrzu. Najczęściej $(68,6 \%)$ byli to przedstawiciele firm prowadzących jednoosobową działalność gospodarczą. Najwięcej respondentów $(52,8 \%)$ reprezentowało przedsiębiorstwa działające powyżej 10 lat. 15,4\% badanych stanowili przedstawiciele firm funkcjonujących 5-10 lat. Zatem zdecydowana większość badanych to przedstawiciele przedsiębiorstw dobrze zakorzenionych na rynku, posiadający wieloletnie doświadczenie, dobrze znający realia, w jakich prowadzą działalność gospodarczą.

Respondentów poproszono o ocenę trudności prowadzenia działalności gospodarczej na terenie Zabrza w 10 stopniowej skali (1 - bardzo trudno, 10 - bardzo łatwo).

Dostępny w Internecie, http://www.bip.um.zabrze.pl/ engine $/ / \mathrm{bip} / 8 / 310 ? \mathrm{o}=\mathrm{tp} 1 \& \mathrm{e}=\mathrm{s} \mid 310$.
Najczęstszą oceną było 5 (20,4\%), druga co do liczności grupa $(15,7 \%)$ wskazała ocenę 8 , a mediana wyniosła 6 , co świadczy, że przedsiębiorcy uważają, iż prowadzenie działalności gospodarczej w Zabrzu ani nie jest bardzo łatwe, ani nad wyraz trudne.

Najistotniejszymi priorytetami dla przedsiębiorstw w ciągu najbliższych 3 lat ocenianymi w pięciostopniowej skali były: rozwój oferty, zdobycie nowych rynków w Polsce oraz inwestycje. We wszystkich tych przypadkach najczęstsza była najwyższa ocena (odpowiednio: 39\%, 35,8\%, 22,9\%); mediana wynosiła odpowiednio 4, 4, 3. Jako mniej istotne cele zostały uznane: pozyskanie inwestorów, zwiększenie zatrudnienia, zdobycie nowych rynków eksportowych oraz zakup nieruchomości. Takie wyniki nie wydają się zaskakujące, ponieważ zdecydowana większość respondentów reprezentowała mikro przedsiębiorstwa (64,8\%), a 61\% firm prowadziło tylko działalność usługową.

Przedsiębiorcy oceniali zabrzańskie instytucje mające wpływ na ich działalność na pięciostopniowej skali (1 - najgorsza, 5 - najlepsza). Kryteria oceny były następujące: 1) zrozumienie potrzeb przedsiębiorcy, 2) jasność i szybkość załatwiania spraw, 3) chęć pomocy i rozwiązywania problemów oraz 4) kompetencje pracowników. Oceniane były: Zabrzańskie Centrum Rozwoju Przedsiębiorczości, Urząd Skarbowy, Zakład Ubezpieczeń Społecznych, Powiatowy Urząd Pracy.

Z usług Zabrzańskiego Centrum Rozwoju Przedsiębiorczości (wydział urzędu miejskiego) nie korzystało aż 43,7\% badanych prawdopodobnie związane to jest $z$ faktem, że działa ono stosunkowo niedługo i być może nie jest dostatecznie rozreklamowane. Osoby mające kontakt z tą instytucją przy każdym kryterium najczęściej przyznawały najwyższą notę. Jedynie w przypadku kryterium zrozumienie potrzeb przedsiębiorcy mediana wyniosła 4, w przypadku pozostałych kryteriów mediana była równa 5 . 
Zrozumienie potrzeb przedsiębiorcy u pracowników Urzędu Skarbowego w Zabrzu zostało ocenione na średnim poziomie mediana była równa 3, natomiast w przypadku pozostałych kryteriów ocena pracowników tego urzędu była dobra - mediana wyniosła 4.

W przypadku Zakładu Ubezpieczeń Społecznych na średnim poziomie (mediana równa 3) oceniono zrozumienie potrzeb przedsiębiorcy u pracowników tej instytucji oraz jasność i szybkość załatwiania spraw, natomiast ocena chęci pomocy i rozwiq̨zywania problemów oraz kompetencje pracowników zostały ocenione na poziomie dobrym (mediana równa 4).

Pracownicy Powiatowego Urzędu pracy z punktu widzenia każdego kryterium zostali ocenieni dobrze - mediany wynosiły 4, w przypadku każdego kryterium przynajmniej $20 \%$ oceniających dało 5 - najczęstszą ocenę.

Przedsiębiorcy przedstawili swoje oczekiwania w odniesieniu do władz lokalnych. Okazało się, że najbardziej pożądane działania to: wsparcie finansowe (np. różnego rodzaju ulgi), pomoc w dostępie do informacji, pomoc i szkolenia w zakresie pozyskiwania środków z UE, doradztwo prawne. Ponieważ Zabrze ma specjalną ofertę zwolnień i ulg podatkowych dla przedsiębiorców, więc wydaje się, że problemem jest słaba znajomość tej oferty. Wśród najmniej pożądanych działań znalazły się poszukiwanie terenów inwestycyjnych oraz poręczenia i gwarancje. Prawdopodobnie łączy to się z faktem, że znaczna część badanych przedsiębiorstw to mikro przedsiębiorstwa i wiele $z$ nich działa w usługach. Z badań wynika, że przedsiębiorcy mają słabe rozeznanie $w$ działaniach podejmowanych przez miasto na rzecz wsparcia przedsiębiorczości, gdyż postulują takie działania, które już są realizowane np. przez Zabrzańskie Centrum Rozwoju Przedsiębiorczości.

Respondenci zostali poproszeni o określenie barier rozwoju przedsiębiorczości w Zabrzu. Interesujące jest, że oprócz typowych barier, takich jak: niejasne przepisy prawne, działalność administracji (opieszałość urzędników, brak przepływu informacji), zbyt wysokie koszty prowadzenia działalności, działalność sklepów wielkopowierzchniowych, przedsiębiorcy zwrócili uwagę na słabość lokalnego kapitału ludzkiego, np. „małą aktywność przedsiębiorcza wśród potencjalnych założycieli firm", " brak pracowników-specjalistów, których można by zatrudnić". Ta ostatnia bariera może wydawać się zaskakująca ze względu na bliskość wielu uczelni i instytutów badawczych. Jednakże wielu młodych ludzi podejmuje decyzję o migracji do innych ośrodków, które dają większe szanse na znalezienie ciekawej i dobrze płatnej pracy, bądź podejmuje pracę w Katowicach lub Gliwicach.

Z badań ankietowych wynika, że lokalne władze powinny dokonać przeglądu stosowanych instrumentów finansowych, które powinny nie tylko istotnie wpływać na decyzję o podjęciu działalności w Zabrzu, ale także wspierać już działające podmioty gospodarcze. Badania wykazały, że istnieją niedostatki w komunikacji z przedsiębiorcami, wielu przedsiębiorców nie wiedziało o już istniejących rozwiązaniach wspierających przedsiębiorczość w Zabrzu, a tym samym zwiększających atrakcyjność miasta pod względem prowadzenia działalności. Wydaje się, że pomoc w zakresie pozyskiwania środków unijnych jest niewystarczająca, zbyt mało jest szkoleń w tym zakresie. Bliskość dużych ośrodków (Katowice, Gliwice) wymaga poszukiwania takich rozwiązań, które pozwoliłyby wykorzystać regionalne obszary niszowe, jeszcze niezagospodarowane przez te „konkurencyjne" ośrodki.

Wyniki badań były m.in. podstawą przeprowadzenia analizy SWOT dla Zabrza w kontekście warunków prowadzenia działalności gospodarczej. Wyodrębniono mocne i słabe miasta w następujących obszarach: demografia, przedsiębiorczość, infrastruktura i ko- 
munikacja, inwestycje, zarządzanie miastem, edukacja, badania i rozwój, rynek nieruchomości, innowacyjność, rekreacja i kultura. Zidentyfikowano szanse i zagrożenia w zakresie: demografii, otoczenia prawnego, rynku pracy, inwestycji, badań i rozwoju, przedsiębiorczości, współpracy międzynarodowej oraz kultury i rekreacji. Na tej podstawie sformułowano Lokalny Planu Rozwoju Przedsiębiorczości dla miasta Zabrze na lata 20162020 (LPRP), który stanowi uszczegółowienie celów strategicznych i kierunków działań w przyjętej Strategii Rozwoju Miasta Zabrze na lata 2008-2020 w zakresie stymulowania przedsiębiorczości oraz poprawy warunków prowadzenia działalności gospodarczej.

W Lokalnym Planie Rozwoju Przedsiębiorczości określono 5 celów, z którymi powiązano priorytety wraz z proponowanymi projektami. Do każdego z celów określono wskaźniki, które mają służyć monitorowaniu realizacji przyjętego planu. Przyjęto następujące cele:

1. Rozwijanie postaw przedsiębiorczych oraz społeczeństwa obywatelskiego; wskaźnik - liczba działań zrealizowanych na rzecz promocji i rozwoju postaw przedsiębiorczych.

2. Rozwijanie instrumentów wspierania przedsiębiorczości; wskaźnik - liczba działań i uczestników.

3. Promocja Zabrza i aktywności zabrzańskich przedsiębiorców na rynkach międzynarodowych; wskaźnik - liczba działań w zakresie promocji Zabrza i aktywności zabrzańskich firm na rynkach międzynarodowych oraz liczba uczestników.

4. Rozwój efektywnego systemu pozyskiwania inwestorów; wskaźnik - liczba i wartość działek inwestycyjnych sprzedanych przez miasto.

5. Kreowanie korzystnych warunków dla prowadzenia działalności gospodarczej; wskaźnik - liczba działań kreujących korzystne warunki dla prowadzenia działalności gospodarczej w Zabrzu oraz liczba uczestników tych działań.
Z celem 1 związane były następujące priorytety ${ }^{2}$ : promocja koncepcji ekonomii społecznej (promocja ekonomii społecznej, a także wsparcie doradcze, szkoleniowe i finansowe dla podmiotów ekonomii społecznej); promocja postaw przedsiębiorczych wśród mieszkańców Zabrza (projekty dla dzieci i młodzieży w zakresie przedsiębiorczości - zajęcia z praktykami, prowadzenie wirtualnej firmy, działania z wykorzystaniem Internetu); włączenie przedsiębiorców w kreowanie środowiska gospodarczego w mieście (Rada Gospodarcza przy Prezydencie Miasta); edukacja na rzecz przedsiębiorczości (rozwój współpracy pomiędzy szkołami i przedsiębiorcami w celu dostosowania szkolnictwa zawodowego i technicznego do rynku pracy); ułatwianie zakładania działalności gospodarczej i wpieranie w jej prowadzeniu (Karta Młodego Przedsiębiorcy); współpraca z instytucjami, organizacjami, urzędami i przedsiębiorstwami na rzecz rozwijania przedsiębiorczości w Zabrzu (dekalog współpracy na rzecz rozwoju przedsiębiorczości).

Z celem 2 związane są dwa priorytety: finansowe instrumenty wspierania przedsiębiorców (dokonanie analizy systemu ulg i zwolnień pod kątem wsparcia firm z sektora MŚP); poprawa dostępności przedsiębiorców do usług doradczo-szkoleniowych (organizacja spotkań informacyjnych, szkoleń, warsztatów i seminariów dla przedsiębiorców oraz osób zainteresowanych rozpoczęciem działalności gospodarczej).

W celu 3 wyodrębniono 2 priorytety: promocja Zabrza i aktywności zabrzańskich przedsiębiorców na rynkach międzynarodowych (promocja Zabrza za granicą jako miasta medycyny - technologie, wiedza, zasoby ludzkie); wspieranie internacjonalizacji działalności gospodarczej (współpraca z Wydziałami Promocji Handlu i Inwestycji przy Ambasadach RP, Regionalną Izbą Gospodar-

\footnotetext{
W nawiasie podano przykładowe projekty związane z danym priorytetem.
} 
czą w Katowicach, Europejską Konfederacją Młodych Przedsiębiorców YES for Europe, Centrum Obsługi Inwestora i Eksportera przy Urzędzie Marszałkowskim w Katowicach, Ministerstwem Rozwoju i innymi w zakresie nawiązywania kontaktów międzynarodowych przez zabrzańskich przedsiębiorców).

Z celem 4 związany był priorytet - system pozyskiwania bezpośrednich inwestycji krajowych i zagranicznych (budowa strony internetowej poświęconej Zabrzu - Europejskiej Stolicy Startupów Medycznych).

W ramach celu 5 przewidziano priorytety: innowacyjne produkty i technologie w zabrzańskich przedsiębiorstwach (promocja systemu współpracy uczelni z sektorem MŚP); promocja usług dla przedsiębiorców oferowanych przez administrację publiczną (promocja działalności Urzędu Miejskiego w Zabrzu w obszarze wspierania rozwoju przedsiębiorczości).

Liczba i zakres realizacji proponowanych projektów zależy od możliwości finansowych i organizacyjnych miasta oraz ewentualnych zewnętrznych źródeł finansowania.

\section{Podsumowanie}

Wyniki badań przeprowadzonych wśród polskich JST wskazują, że jednostki te w przeważającej większości w zakresie wspierania przedsiębiorczości ograniczają się jedynie do "standardowych" działań, tj. wykorzystują, w różnym zakresie, instrumenty finansowe, inwestują (przeważnie w infrastrukturę komunikacyjną i komunalną) oraz prowadzą działalność promocyjną. Rzadko spotykana jest systematyczna współpraca i konsultacje z lokalnymi przedsiębiorcami na rzecz rozwoju przedsiębiorczości. Tylko nieliczne JST prowadzą dogłębne badania warunków prowadzenia działalności gospodarczej na ich terenie, z udziałem lokalnych przedsiębiorców, z których wnioski umożliwiają podejmowanie odpowiednich, kompleksowych, często innowacyjnych działań, wspierają- cych przedsiębiorczość, a w konsekwencji lokalny rozwój. Wydaje się, że podejście do problemu wspierania lokalnej przedsiębiorczości w sposób systemowy, poprzedzony odpowiednimi badaniami, umożliwiającymi całościowe spojrzenie na problem, może prowadzić do wypracowania innowacji społecznych, rzutujących na lokalny rozwój.

W literaturze funkcjonuje wiele definicji innowacji społecznej. W każdej z nich można wskazać najistotniejsze elementy, którymi są działania prowadzące do istotnej zmiany w aspekcie życia społecznego. W artykule oparto się na definicji Caulier-Grice i współautorów [2012], mówiącej, że innowacje społeczne to nowe rozwiązania (usługi, produkty, procesy itd.), które skuteczniej niż dotychczasowe rozwiązania odpowiadają na potrzeby społeczne i umożliwiają lepsze wykorzystanie potencjału i zasobów. Innowacje społeczne są zarówno dobre dla społeczeństwa, jak i zwiększają zdolność społeczeństwa do działania.

Wydaje się, że w kontekście przytoczonej definicji wdrożenie Lokalnego Planu Rozwoju Przedsiębiorczości dla Miasta Zabrze na lata 2016-2020, a zwłaszcza niektórych rozwiązań w nim przyjętych można uznać za innowację społeczną. W szczególności do innowacji społecznych można zaliczyć:

- utworzenie przez Urząd Miasta Zabrze Zabrzańskiego Centrum Rozwoju Przedsiębiorczości, które jako wydział urzędu zajmuje się wszelkimi działaniami wspierającymi przedsiębiorczość w Zabrzu,

- wprowadzenie Karty Młodego Przedsiębiorcy, która pozwala młodym przedsiębiorcom do korzystania ze zniżek i ulg na różnego rodzaju usługi oferowane przez lokalne firmy i instytucje,

- organizacja cyklicznych spotkań „spotkanie śniadanie" w celu nawiązywania nowych kontaktów przez przedsiębiorców i integracji środowiska lokalnego przedsiębiorców. 
Na podstawie badań opisanych wcześniej można stwierdzić, że te rozwiązania warte są szerszego rozpropagowania.

\section{Literatura}

Ciura G., Grycuk A., Korolewska M., Russel P., Smołkowska U., Stachurska-Waga M., Wołodkiewicz-Donimirski Z., Zgliczyński W. (2013). Wspieranie rozwoju przedsiębiorczości przez jednostki samorzadu terytorialnego w Polsce - raport z badań. Warszawa: Wydawnictwo Sejmowe.

Caulier-Grice J., Davies A., Patrick R., Norman W. (2012). Defining Social Innovation. A deliverable of the project: "The theoretical, empirical and policy foundations for building social innovation in Europe" (TEPSIE), European Commission - 7 th Framework Programme. Brussels: European Commission, DG Research.

Cyfert Sz., Dyduch W., Latusek-Jurczak D., Niemczyk J., Sopińska A. (2014). "Subdyscypliny w naukach o zarządzaniu - logika wyodrębniania, identyfikacja modelu koncepcyjnego oraz zawartość tematyczna", Organizacja i Kierowanie, 1 (161), s. $37-48$.

Dziemianowicz W., Mackiewicz M., Malinowska E., Misiąg W., Tomalak M. (2000). Wspieranie przed- siębiorczości przez samorząd terytorialny. Warszawa: PAB-Font S.C.

GUS (2016). Wybrane wskaźniki przedsiębiorczości w latach 2010-2014. Warszawa: Zakład Wydawnictw Statystycznych.

Kożuch A. (2011). "Rola samorządu terytorialnego we wspieraniu rozwoju lokalnego", w: A. Kożuch, A. Noworól (red.), Instrumenty zarządzania rozwojem w przedsiębiorczych gminach (s. 9-26). Kraków: Instytut Spraw Publicznych Uniwersytetu Jagiellońskiego.

Lokalny Plan Rozwoju Przedsiębiorczości dla miasta Zabrze na lata 2016-2020, http://www.bip. um.zabrze.pl/engine//bip/8/310?o=tp1\&e=s|310.

Matejun M. (2012). „Regionalne instrumenty wspierania rozwoju małych i średnich przedsiębiorstw", w: A. Adamik (red.), Współpraca małych i średnich przedsiębiorstw w regionie. Budowanie konkurencyjności firm i regionu (s. 82-109). Warszawa: Difin.

Skica T., Bem A. (2014). „Rola samorządu terytorialnego $\mathrm{W}$ procesach stymulowania przedsiębiorczości", "Studia Regionalne i Lokalne”, 1 (55), s. 79-92.

\section{Local social innovation supporting the development and functioning of entrepreneurship}

Summary: The state of local entrepreneurship is strongly influenced by actions undertaken by local self-government units. Research shows that the most common ways of support for entrepreneurship are limited to the use of various financial instruments and promotional activities. The aim of the article is to present innovative, systematized, locally-undertaken social innovations in Zabrze - novel solutions to support the development and functioning of entrepreneurship. The application of these innovative solutions should bring specified, useful and measurable benefits to society. These activities are included in the "Local Entrepreneurship Program for 2016-2020".

Keywords: public governance, social innovation, supporting of entrepreneurship.

\section{Prawa autorskie i licencja / Copyright and License}

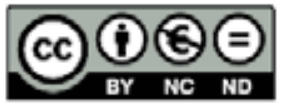

Artykuł opublikowano na licencji Creative Commons

Uznanie autorstwa - Użycie niekomercyjne - Bez utworów zależnych 3.0 Polska http://creativecommons.org/licenses/by-nc-nd/3.0/pl/

This article is published under the terms of the Creative Commons Attribution - NonCommercial - NoDerivs (CC BY-NC-ND 3.0) License

http://creativecommons.org/licenses/by-nc-nd/3.0/ 